O. O. SALIY ${ }^{1}$ (https://orcid.org/0000-0001-7103-2083),

O. V. LOS ${ }^{2}$ (https://orcid.org/0000-0002-7830-6937),

O. P. BAULA ${ }^{1}$ (https://orcid.org/0000-0003-4305-6517),

V. U. TURCHYNA ${ }^{1}$ (https://orcid.org/0000-0003-3046-5549

${ }^{1}$ Kyiv National University of Technologies and Design

${ }^{2}$ Pharmaceutical Corporation «Yuria-Pharm», Kyiv

\title{
DEVELOPMENT OF COMPOSITION AND EVALUATION OF EQUIVALENCE OF DIACEREIN HARD GELATIN CAPSULES
}

Key words: diacerein; solubility; pharmaco-technological properties; dissolution kinetics

О. О. САЛІЙ ${ }^{1}$ (https://orcid.org/0000-0001-7103-2083), канд. фарм. наук, доцент,

О. В. ЛОСЬ ${ }^{2}$ (https://orcid.org/0000-0002-7830-6937),

О. П. БАУЛА ${ }^{1}$ (https://orcid.org/0000-0003-4305-6517), канд. хім. наук, доцент,

В. Ю. ТУРЧИНА ${ }^{1}$ (https://orcid.org/0000-0003-3046-5549)

${ }^{1}$ Київський національний університет технологій та дизайну

${ }^{2}$ Фармачевтична корпорачія «Юрія-Фарм», м. Київ

РОЗРОБЛЕННЯ СКЛАДУ І ОЦІНКА ЕКВІВАЛЕНТНОСТІ ТВЕРДИХ

ЖЕЛАТИНОВИХ КАПСУЛ НА ОСНОВІ ДІАЦЕРЕЇНУ

Ключові слова: діацереїн, розчинність, фармако-технологічні властивості, кінетика розчинення

Osteoarthrosis (OA) remains the most common form of joint damage and one of the main causes of disability, which causes impairment of quality of life and significant financial costs, especially in elderly people [1]. Non-steroidal anti-inflammatory drugs (NSAIDs) are the first-line symptomatic treatment for pain syndrome in the treatment of OA [2]. However, treatment with NSAIDs is compromised by the fact that most patients are elderly and have a wide range of comorbidities, resulting in increased risk of adverse reactions. Systemic adverse reactions caused by NSAIDs include: disorders of the gastrointestinal tract, disorders of the blood system, cardiovascular system, central nervous system [3]. Therefore, the emergence of drugs with sufficient efficacy, well tolerated and accepted for long-term pharmacotherapy of OA becomes particularly interesting. These new generation drugs are based on diacerein (4,5-bis(acetyloxy)-9,10-dioxo-2-anthracenocarboxylic acid) that is used as a symptomatic prolonged action drug for OA treatment. Diacerein when taken orally shows moderate anti-inflammatory and analgesic activity, slows down the breakdown of cartilage, relieves pain and swelling [4]. The effect of Diacerein is manifested during 2-4 months of treatment and has a unique mechanism of action, which differs from the mechanism of action of NSAIDs. Diacerein and its active metabolite rhein have an anti-pain effect while not inhibiting prostaglandin synthesis and, therefore, no gastroduodenal side-effects. Diacerein not absorbed in the large intestine is converted to rhein, which is responsible for loosening and diarrhoea, which is one of the main adverse reactions when diacerein -based medications are used [5]. However, recent studies have shown that rhein is a potential therapeutic agent for the treatment of SARS-CoV infection, so diacerein is a multi-purpose drug useful for the treatment of COVID-19 [6].

In the pharmaceutical development of a medicinal product (MP) based on diacerein for oral administration, special attention should be paid to biopharmaceutical aspects that affect the bioavailability. Variable biopharmaceutical factors, which include physicochemical properties of API, qualitative and quantitative composition of excipients, features of the technological process can affect the therapeutic equivalence of generic drugs by changing their pharmacokinetic parameters [7]. Solubility is one of the factors that determine the bioavailability of the drug during oral administration [8]. New generation drugs tend to (C) Колектив авторів, 2021 
have structures and design of molecules with higher lipophilicity, higher molecular weight and lower dispersibility in aqueous solutions [9]. It is known that over the last few decades, the number of developed APIs has increased significantly, which due to solubility problems fell into classes II and IV of the biopharmaceutical classification system (BSC), because API molecules during development had a higher average molecular weight, higher melting points and more high degree of hydrophobicity [4]. Diacerein due to its physicochemical properties is practically insoluble in water $(3,197 \mathrm{mg} / \mathrm{ml})$ and belongs to BSC II class, therefore only $35-56 \%$ of drug reaches systemic circulation [5]. The range of medicinal product containing diacerein for oral administration in the Ukrainian pharmaceutical market is very limited, represented by the foreign drug «Orcerin» capsules of $50 \mathrm{mg}$, manufacturer McLeods Pharmaceuticals Limited, India, and domestic products: «Flexerin» $50 \mathrm{mg}$ in capsules, manufacturer JSC «Kyiv Vitamin Plant» and «Diamax» $50 \mathrm{mg}$ in capsules manufacturer LLC «Farmex Group», Ukraine, and the registration certificate of the original medication "Artrodar», manufactured by TRB Pharma S. A. Argentina, $50 \mathrm{mg}$ capsules, has been suspended [10]. Increasing market availability of drugs in this group encourages the development of composition and search for the latest technological aspects of their industrial production, which is an important area of pharmacy today. Therefore, the search for approaches to increase the solubility of practically insoluble API using the formulation, composition of excipients, the use of API with specified physicochemical characteristics, assessment of impurity profile, solubility and kinetics of release of the substance from hard gelatin capsules should ensure guaranteed efficacy and safety of medicines [11].

Aim - development of the formulation of solid gelatin capsules based on diacerein, experimental study of diacerein solubility and evaluation of the formulation by in vitro comparative studies of the dissolution kinetics of the medicinal product.

\section{Mat e rials and methods}

The composition of the capsules with diacerein was developed using the API manufacturing of Taizhou Highsun Pharmaceutical Co., Ltd, China. In terms of quality parameters and physical and chemical characteristics the API were fully meets European Pharmacopoeia requirements [12] and is a substance practically insoluble in water.

Determination of $\mathrm{pH}$-dependent solubility of diacerein was performed for the concentration of the highest single dose in $250 \mathrm{ml}$ of buffer solutions in the range of $\mathrm{pH}$ 1.2-6.8 at a temperature of $37 \pm 1^{\circ} \mathrm{C}$. The $\mathrm{pH}$ of each buffer solution was checked before and after the introduction of the active substance into the buffer solution [13].

Conditions for API solubility studies: volume of dissolution medium $250 \mathrm{ml}$; dissolution media temperature $37.0 \pm 1{ }^{\circ} \mathrm{C}$; dissolution media: buffer solutions with $\mathrm{pH} 1.2(0.1 \mathrm{M} \mathrm{HCl})$, pH 4.5 (acetate buffer) and pH 6.8 (phosphate buffer); sampling time for buffer solutions pH 1.2 and 4.5 was 15, 30, 45, 60 minutes, for buffer solution pH 6.8 was 10, 15, 20 minutes.

Quantitative content of diacerein that released into the buffer solution was determined by absorption spectrophotometry in the ultraviolet region at a wavelength of $343 \mathrm{~nm}$ in a cuvette with an optical layer thickness of $10 \mathrm{~mm}$ on a spectrophotometer Lambda 35 (Perkin Elmer, USA). The following auxiliary substances were used for the optimal composition of capsule mass: Lactose monohydrate (Granulac 200) (Molkerei Meggle Wasserburg GmbH\& Co. KG, Germany); povidone K 29/32 (ISP, Switzerland); croscarmellose sodium (Solutab A) (Blanver Farmoquímica, Ltd, Brazil); colloidal silicium dioxide (Orisil 300) Kalush Test Experimental Plant of Surface Chemistry Institute of National Academy of Science of Ukraine, LTD «Orisil», Ukraine), magnesium stearate (LTD «Electrogasohim», Ukraine), $\beta$-cyclodextrin (Zibo Senlos Import \& Export Co., Ltd., China).

The capsule mass was prepared according to the following technology: sieved through a calibrator of conical type and weighed raw material was loaded into a high- 
speed mixer-granulator (High-shear mixer) in the sequence: Lactose monohydrate, croscarmellose sodium, diacerein (in terms of anhydrous substance), silicon dioxide colloidal anhydrous. The mass is thorough kneaded. The resulting component mixture was granulated by stirring in a granulator by continuously feeding a $10 \%$ solution of Povidon $\mathrm{K}$ 29/32 as a granulation agent via a nozzle. The obtained moistened mixture was mixed and dried by means of a shelf drier at $55{ }^{\circ} \mathrm{C}$, calibrated through a calibrator of conical type with a bore diameter of $2 \mathrm{~mm}$ and the obtained capsule mass was powdered with magnesium stearate.

Physico-chemical and pharmaco-technological properties of the capsule mass and the finished pharmaceutical form were investigated according to the methodology of the State Pharmacopoeia of Ukraine (SPU) [14] and/or European Pharmacopoeia. The quality of the obtained capsule mass was evaluated according to the following pharmaco-technological parameters: external appearance of the capsule mass; bulk density; density after shrinkage.

In comparative studies of the developed samples of the drug based on diacerein used as a reference drug Artrodarin ${ }^{\circ}, 50 \mathrm{mg}$ capsules, manufactured by TRB PHARMA S. A., Argentina.

Comparative studies of the dissolution kinetics of the reference drug Artrodarin ${ }^{\circledR}$, $50 \mathrm{mg}$ capsules and the investigated drug samples were performed in vitro using the «Dissolution» test. The test was carried out using 12 dosage units of each investigated medicines, which were individually placed into the round-bottom dissolution flask of apparatus with a paddle, maximizing avoiding the formation of air bubbles on the surface of the drug. Conditions for the test «Dissolution»: Type of device: apparatus with a paddle; agitation speed $75 \mathrm{rpm}$; volume of dissolution medium: $900 \mathrm{ml}$; temperature of dissolution: $37.0 \pm$ $0.5^{\circ} \mathrm{C}$; dissolution medium: buffer solution with $\mathrm{pH} 6.8$ (phosphate buffer); volume of selected samples: $10 \mathrm{ml}$; sampling method: manual. The amount of diacerein released into the buffer solution was determined by absorption spectrophotometry in the ultraviolet region, under the conditions described above. The comparison solution was prepared by dissolution a standard sample of Diacerein (Y0001595, Sigma-Aldrich) in a suitable dissolution medium.

The results of the studies carried out were expressed as a percentage of the nominal diacerein content in a drug unit. The similarity factor $\left(f_{2}\right)$ of drug dissolution kinetics was calculated using the formula mathematically to demonstrate and discuss drug similarity profiles [13].

Statistical processing of the obtained results was performed with the calculation of the arithmetic mean $(x)$ and the error of the arithmetic mean $(m)$ using regression and correlation analyzes in the ANOVA program, the difference was considered to be significant at $p<0.05$.

\section{Results and discussion}

It is known that diacerein is practically insoluble in water $P$, is a hydrophobic substance, is not wetted by water and exhibits surface hydrophobic properties relative to water, so at the first stage of the study studied the solubility (API) in buffer media simulating oral administration of the drug to determine the dependence dissolution from $\mathrm{pH}$. To study the solubility of diacerein, the highest recommended single dose was calculated, which according to the instructions for medical use is $50 \mathrm{mg}$.

Measurement of the $\mathrm{pH}$ of the dissolution medium was provide before and after adding the substance to the buffer solution. It is known that in solutions with a pH below 3.0 diacerein is insoluble, so in a buffer solution with a $\mathrm{pH}$ of 1.2 insoluble diacerein crystals were filtered off and the $\mathrm{pH}$ value in the filtrate was measured. The results are given in Table 1. 
The results of determining the stability of buffer media by measuring the $\mathrm{pH}$ at the beginning and end of the experiment $(n=3)$

\begin{tabular}{|l|c|c|}
\hline \multicolumn{1}{|c|}{ Dissolution medium } & $\begin{array}{c}\text { The pH value before the } \\
\text { experiment }\end{array}$ & $\begin{array}{c}\text { The pH value after the } \\
\text { experiment }\end{array}$ \\
\hline Buffer solution $\mathrm{pH} 1.2$ & $1.20 \pm 0.01$ & $\begin{array}{c}1.18 \pm 0.02 \\
\text { (filtrate) }\end{array}$ \\
\hline Acetate buffer solution $\mathrm{pH} 4.5$ & $4.51 \pm 0.02$ & $4.53 \pm 0.01$ \\
\hline Phosphate buffer solution $\mathrm{pH} 6.8$ & $6.80 \pm 0.02$ & $6.78 \pm 0.01$ \\
\hline
\end{tabular}

As can be seen from the data presented, the substance diacerein in the studied media does not react chemically and does not affect the value or change in $\mathrm{pH}$ of all buffer solutions, the substance is not destroyed by the formation of decomposition products.

The results of the dissolution of diacerein in three dissolution medium are shown in Table 2.

Ta b 1 e 2

The results of the study of the solubility of diacerein in three buffer media

\begin{tabular}{|c|c|c|}
\hline \multirow{2}{*}{ Dissolution medium } & $\begin{array}{c}\text { Selection time, } \\
\text { min }\end{array}$ & $\begin{array}{c}\text { The concentration of diacerein in the } \\
\text { selected samples, mg/ml }\end{array}$ \\
\hline \multirow{3}{*}{ Hydrochloric acid solution pH 1.2 } & 15 & 0.000184 \\
\cline { 2 - 3 } & 30 & 0.000246 \\
\cline { 2 - 3 } & 45 & 0.000349 \\
\cline { 2 - 3 } & 60 & 0.000425 \\
\cline { 2 - 3 } & 15 & 0.00629 \\
\cline { 2 - 3 } & 30 & 0.007803 \\
\cline { 2 - 3 } & 45 & 0.00951 \\
\cline { 2 - 3 } & 60 & 0.01179 \\
\hline \multirow{3}{*}{ Phosphate buffer solution pH 6.8 } & 10 & 0.186 \\
\cline { 2 - 3 } & 15 & 0.194 \\
\cline { 2 - 3 } & 20 & 0.195 \\
\hline
\end{tabular}

The obtained experimental data confirm that in a buffer solution with a $\mathrm{pH}$ of 1.2 diacerein is practically insoluble. It was also found that diacerein substances in a buffer solution with a $\mathrm{pH}$ of 4.5 has a relatively low solubility, while the solubility of diacerein increases slightly with increasing $\mathrm{pH}$ values of the medium. The obtained experimental data on the low solubility of the active substance confirm the belonging of diacerein to class II according to BSC. Therefore, excipients that increase the solubility of the active substance are a critical parameter in the development of a capsule mass that significantly affects the bioavailability of class II BSC substances.

The development of the composition of the drug Diacerein, capsules, $50 \mathrm{mg}$ consisted in considering the possibility of using various types of excipients and their modifications to achieve optimal pharmacological and technological properties of the capsule mass (flowability, bulk density, Carr\&apos;s index) and the release profile of the active substance.

Due to the poor fluidity and low bulk density of API [4], wet granulation technology was used to obtain the capsule mass, as described above, since the direct encapsulation technology does not allow obtaining a product that meets the requirements of the pharmacopoeia in terms of «Uniformity of dosage units». To create the optimal composition of the capsule mass with diacerein using wet granulation technology, fillers (lactose monohydrate), 
granulating agents (povidon K29/32), disintegrants (sodium croscarmellose), solubilizers ( $\beta$-cyclodextrin and sodium and magnesium stearate) were tested, in accordance with the qualitative composition of the reference drug. The choice of the composition was carried out using a one-factor experiment according to the matrix given in Table 3.

$\mathrm{T}$ a b le 3

Formulation of diacerein experimental samples and comparison drug in the form of hard gelatin capsules

\begin{tabular}{|l|c|c|c|c|c|c|}
\hline \multicolumn{1}{|c|}{ Ingredients, mg } & C1 & C2 & C3 & C4 & C5 & Artrodarin \\
\hline Diacerein & 50.0 & 50.0 & 50.0 & 50.0 & 50.0 & 50.0 \\
\hline$\beta$-Cyclodextrin & - & 10.0 & - & - & - & - \\
\hline Sodium lauryl sulfate & - & 5.0 & - & 4.5 & - & - \\
\hline Lactose monohydrate & 248.5 & 216.0 & 220.3 & 244.0 & 217.8 & + \\
\hline Povidone K29/32 & - & - & 11.5 & - & 13.25 & + \\
\hline Croscarmellose sodium & - & 12.0 & 11.5 & - & 11.75 & + \\
\hline Colloidal anhydrous silica (Aerosil) & - & 6.0 & 5.5 & - & 5.75 & + \\
\hline Magnesium stearate & 1.5 & 1.0 & 1.2 & 1.5 & 1.45 & + \\
\hline Hard gelatin capsules, № capsules & 1 & 1 & 1 & 1 & 1 & 1 \\
\hline Weight per capsule, mg & 300 & 300 & 300 & 300 & 300 & 300 \\
\hline
\end{tabular}

Pharmaco-technological properties of the mass for encapsulation of the studied batches of the drug and the reference drug Arthrodarin ${ }^{2}$, capsules, $50 \mathrm{mg}$ are given in Table 4.

$\mathrm{T}$ a b 1 e 4

Pharmaco-technological properties of the mass for encapsulation containing diacerein $(n=3)$

\begin{tabular}{|c|c|c|c|c|c|c|}
\hline \multirow[b]{2}{*}{$\begin{array}{c}\text { Capsule mass } \\
\text { quality indicators }\end{array}$} & \multicolumn{6}{|c|}{ The results obtained } \\
\hline & $\begin{array}{c}\text { Composition } \\
1\end{array}$ & $\begin{array}{c}\text { Composition } \\
2\end{array}$ & $\begin{array}{c}\text { Composition } \\
\mathbf{3}\end{array}$ & $\begin{array}{c}\text { Composition } \\
4\end{array}$ & $\begin{array}{c}\text { Composition } \\
5\end{array}$ & $\begin{array}{c}\text { Capsule } \\
\text { mass } \\
\text { Arthrodarin }\end{array}$ \\
\hline Appearance & $\begin{array}{l}\text { Yellow } \\
\text { granules }\end{array}$ & $\begin{array}{l}\text { Yellow } \\
\text { granules }\end{array}$ & $\begin{array}{l}\text { Yellow } \\
\text { granules }\end{array}$ & $\begin{array}{l}\text { Yellow } \\
\text { granules }\end{array}$ & $\begin{array}{l}\text { Yellow } \\
\text { granules }\end{array}$ & $\begin{array}{l}\text { Yellow } \\
\text { granules }\end{array}$ \\
\hline Loss on drying, $\%$ & $2.84 \pm 0.01$ & $2.38 \pm 0.01$ & $2.47 \pm 0.01$ & $2.52 \pm 0.01$ & $2.48 \pm 0.01$ & $4.50 \pm 0.01$ \\
\hline $\begin{array}{l}\text { Bulk density } \mathrm{m} / \mathrm{V}_{0} \text {, } \\
\mathrm{g} / \mathrm{ml}\end{array}$ & $\begin{array}{c}0.671 \pm \\
0.01\end{array}$ & $\begin{array}{c}0.638 \pm \\
0.01\end{array}$ & $\begin{array}{c}0.625 \pm \\
0.01\end{array}$ & $\begin{array}{c}0.603 \pm \\
0.01\end{array}$ & $\begin{array}{c}0.628 \pm \\
0.01\end{array}$ & $0.68 \pm 0.01$ \\
\hline $\begin{array}{l}\text { Tapped density, } \mathrm{m} / \\
\mathrm{V}_{2500}, \mathrm{~g} / \mathrm{ml}\end{array}$ & $\begin{array}{c}0.671 \pm \\
0.01 \\
\end{array}$ & $\begin{array}{c}0.638 \pm \\
0.01 \\
\end{array}$ & $\begin{array}{c}0.625 \pm \\
0.01 \\
\end{array}$ & $\begin{array}{c}0.603 \pm \\
0.01 \\
\end{array}$ & $\begin{array}{c}0.628 \pm \\
0.01\end{array}$ & $0.68 \pm 0.01$ \\
\hline Carr index, $\%$ & 30.12 & 21.62 & 16.67 & 24.81 & 20.40 & 12.82 \\
\hline $\begin{array}{l}\text { Flowability, } \mathrm{s} / 100 \mathrm{~g} \\
\text { of sample, }(\mathrm{g} / \mathrm{s}) ; \\
\text { funnel with } \\
d=15 \mathrm{~mm}\end{array}$ & $\begin{array}{c}4.61 \pm 0.05 \\
(21.22)\end{array}$ & $\begin{array}{c}4.22 \pm 0.05 \\
(23.81)\end{array}$ & $\begin{array}{c}3.82 \pm 0.05 \\
(26.18)\end{array}$ & $\begin{array}{c}4.25 \pm 0.05 \\
(23.09)\end{array}$ & $\begin{array}{c}4.23 \pm 0.05 \\
(23.64)\end{array}$ & $\begin{array}{c}3.39 \pm 0.05 \\
(29.49)\end{array}$ \\
\hline Similarity factor $f_{2}$ & $<50$ & $>50$ & $>50$ & $<50$ & $>50$ & $>50$ \\
\hline
\end{tabular}

As can be seen from the data presented in Table 4, compositions No 1 and No 4 have unsatisfactory technological properties (poor flowability and high Carr index), and are not similar to the reference drug (similarity factor below 50). The analysis of the pharmaco-technological properties of the mass for encapsulation showed that Composition No 3 is optimal. Lactose monohydrate (Granulac 200) was used as a filler, and a $10 \%$ solution of povidone K 29/32 was used as a granulating agent. Colloidal silicon dioxide (Orisil 300 ), which is a highly dispersed amorphous powder with a particle size of about $40 \mathrm{~nm}$. 
Glissants (sliding substances) should be added to the composition of the mass for encapsulation precisely in a highly dispersed state. The greater the degree of grinding, the larger the surface of the mass for encapsulation, with the same amount they can cover. Another function that gliders perform is to remove the electrostatic charge from the granulate, which also improves their flowability. Anhydrous colloidal silicon dioxide, introduced into the composition No 3, made it possible to achieve optimal flowability of the capsule mass. Croscarmellose sodium was used to disintegrate the capsules in order to ensure the required disintegration time of the capsules and the release of the active substance. The conducted pharmacological and technological studies allow us to assert that the resulting mass for encapsulating composition No 3 can be used to develop hard gelatin capsules of the diacerein preparation. The obtained data for the bulk density and Carr\&apos;s coefficient indicate satisfactory flowability of the encapsulating mass.

The next stage of research was the development of an experimental series of capsules with diacerein and comparative studies of pharmaco-technological and physico-chemical parameters of generic and reference drugs are given in Table 5.

Table 5

Comparison of pharmaco-technological properties of the studied drug based on diacerein, $50 \mathrm{mg}$ capsules and the reference drug Arthrodarin ${ }^{\circledR}, 50 \mathrm{mg}$ capsules

\begin{tabular}{|c|c|c|c|}
\hline \multirow[b]{2}{*}{ Quality indicator } & \multicolumn{2}{|c|}{ The results obtained } & \multirow[b]{2}{*}{$\begin{array}{l}\text { Control } \\
\text { method }\end{array}$} \\
\hline & $\begin{array}{c}\text { Diacerein, } \\
50 \text { mg capsules, } \\
\text { S. } 001\end{array}$ & $\begin{array}{l}\text { Artrodarin }{ }^{\circledR}, \\
50 \text { mg capsules, } \\
\text { S. OY419 }\end{array}$ & \\
\hline $\begin{array}{l}\text { Appearance of } \\
\text { capsules }\end{array}$ & $\begin{array}{l}\text { Hard gelatin capsules № } 1 \text {, } \\
\text { consisting of a blue body and an } \\
\text { opaque white cap. The capsules } \\
\text { contain yellow granules }\end{array}$ & $\begin{array}{l}\text { Hard gelatin capsules № } 1 \text { with } \\
\text { a green body and a white cap, } \\
\text { containing a mixture of powder } \\
\text { and yellow granules }\end{array}$ & Visually \\
\hline Loss on drying, $\%$ & 4.5 & 4.8 & EP, 2.2.32 \\
\hline \multirow{2}{*}{$\begin{array}{l}\text { Average weight of } \\
\text { capsule contents } \\
\text { (average value of } 10 \\
\text { capsules), mg }\end{array}$} & $\begin{array}{l}\text { From } 277.5 \mathrm{mg} \\
\text { to } 322.5 \mathrm{mg}( \pm 7.5 \%)\end{array}$ & $\begin{array}{c}\text { From } 285 \mathrm{mg} \\
\text { to } 315 \mathrm{mg}( \pm 5 \%)\end{array}$ & \multirow{2}{*}{ Calculated } \\
\hline & 298.0 & 302.0 & \\
\hline \multirow{2}{*}{$\begin{array}{l}\text { Capsule disintegration } \\
\text { time (average value of } \\
6 \text { capsules), min }\end{array}$} & $\begin{array}{c}\text { No more than } 30 \mathrm{~min} \\
\text { using disks }\end{array}$ & No more than $30 \mathrm{~min}$ & \multirow[t]{2}{*}{ EP, 2.9.1 } \\
\hline & 16 & 11 & \\
\hline \multirow{2}{*}{$\begin{array}{l}\text { Dissolution (average } \\
\text { value of } 6 \text { capsules), } \\
\%\end{array}$} & \multicolumn{2}{|c|}{ No less $75 \%(\mathrm{Q})$ by $30 \mathrm{~min}$} & \multirow{2}{*}{ EP. 2.9 .3} \\
\hline & $89 \%$ & $91 \%$ & \\
\hline \multirow{2}{*}{$\begin{array}{l}\text { Quantitative } \\
\text { content of diacerein, } \\
\mathrm{mg}\end{array}$} & \multicolumn{2}{|c|}{ From 47.5 to $52.5 \mathrm{mg}( \pm 5 \%)$} & \multirow{2}{*}{ EP. 2.2 .25} \\
\hline & 50.79 & 52.0 & \\
\hline
\end{tabular}

As can be seen from the given data in Table 5, the obtained pharmaco-technological and physicochemical parameters of capsules with diacerein are maximally similar for the reference and investigated drugs.

According to the results of testing the test «Dissolution» of diacerein, which at a certain time of sampling passed into the dissolution medium, the average values of the quantitative content and the relative standard deviation were calculated. It was experimentally established that in a buffer medium with a $\mathrm{pH}$ of 1.2 in the interval of $60 \mathrm{~min}$. the release of diacerein is $2.66 \%$ and $15.74 \%$ in a buffer medium with a $\mathrm{pH}$ of 4.5 in the reference and investigational drugs. According to observations in both the generic drug and the reference drug, more than $85 \%$ of the API goes into solution within 30 minutes and earlier in a buffer 
solution with a $\mathrm{pH}$ of 6.8 , which confirms the properties of diacerein to a greater tendency dissolve in media with a neutral $\mathrm{pH}$.

The dependence of the dissolution rate $(X, \%)$ of diacerein on the dissolution time $(\mathrm{t}, \mathrm{min})$ in the buffer solution with $\mathrm{pH} 6,8$ is presented in Figure.

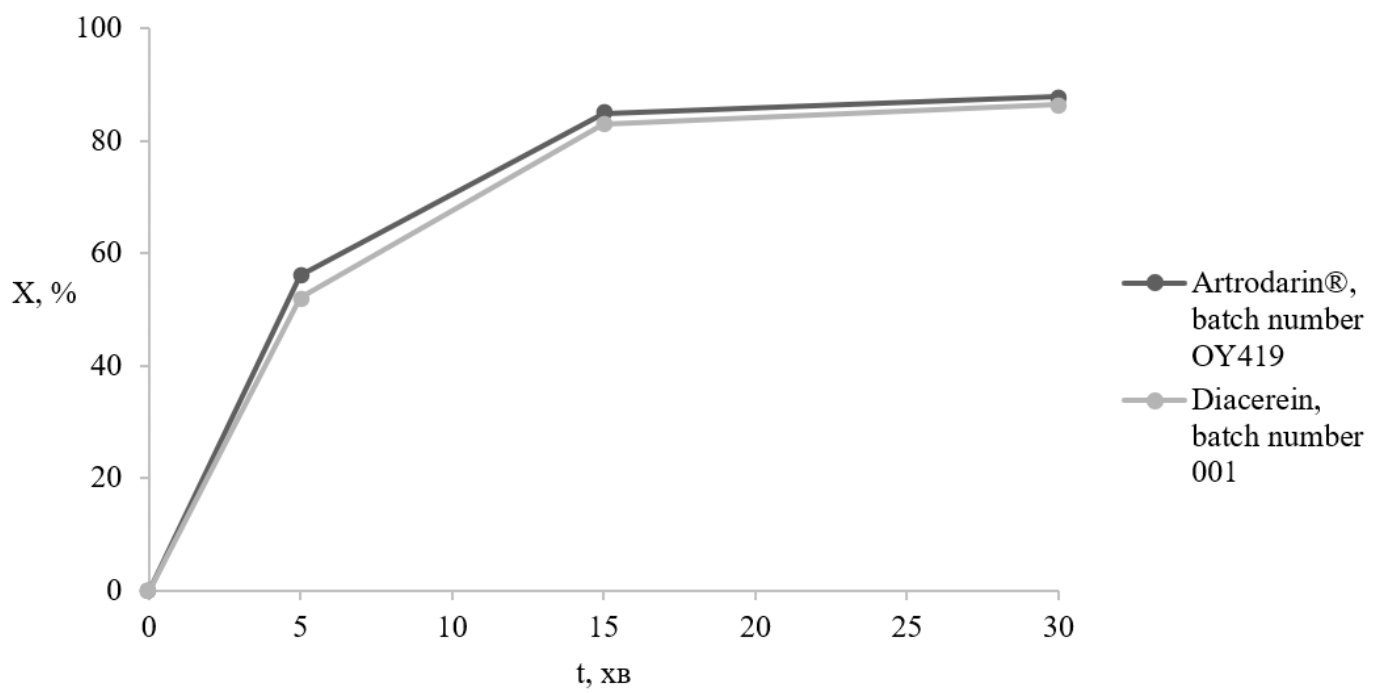

Fig. Dissolution profiles of the reference drug Arthrodarin ${ }^{\circledR}$ and the study sample of the drug based on diacerein

The results of the evaluation of the similarity of the dissolution profiles of the studied samples with the dissolution profile of the reference drug Arthrodarin ${ }^{\circledR}, 50 \mathrm{mg}$ capsules, which were obtained by the formula for calculating the similarity factor $\left(f_{2}\right)$, are given in Table 6.

T a b 1 e 6

The value of the similarity factor of the study drug based on diacerein and the reference drug Artrodarin ${ }^{\circledR}, 50$ mg capsules in buffer media

\begin{tabular}{|c|c|}
\hline Dissolution medium & $\begin{array}{c}\text { Similarity factor } \boldsymbol{f}_{2} \\
\text { (must be between } \mathbf{5 0} \text { and 100) }\end{array}$ \\
\hline $\mathrm{pH}=1.2$ & 99.8 \\
\hline $\mathrm{pH}=4.5$ & 77 \\
\hline $\mathrm{pH}=6.8$ & 74 \\
\hline
\end{tabular}

Therefore, according to the calculations, the obtained values of the similarity factor are in the range from 50 to 100 , which indicates the similarity of the dissolution profiles of the investigated drug based on diacerein and the reference drug Artrodarin, capsules of $50 \mathrm{mg}$ in buffer media with $\mathrm{pH} 1.2,4.5$ and 6.8. The developed composition of capsules based on diacerein is equivalent in dissolution kinetics to the reference drug Artrodarin ${ }^{\circledR}$.

\section{Con c l us i on}

1. The solubility of the diacerein substance in buffer media simulating oral administration of the drug was studied, and it was found that diacerein is practically insoluble in a buffer solution with a $\mathrm{pH}$ of 1.2 , has a relatively low solubility in a buffer solution with a $\mathrm{pH}$ of 4.5 , while the solubility of diacerein increases with increasing $\mathrm{pH}$ values of the medium to 6.8 .

2. An optimal composition has been developed for creating a capsule mass with diacerein using wet granulation technology. Selected fillers, humectants, disintegrants, and 
lubricants were selected to achieve the proper flow properties and short capsules disintegration time for API release. The obtained data for the bulk density and Carr\&apos;s index indicate satisfactory flowability of the encapsulating mass.

3. Comparative studies of the dissolution kinetics of the investigated drug based on diacerein and the reference drug Artrodarin ${ }^{\circledR}$, capsules of $50 \mathrm{mg}$ were carried out. According to the calculations, the obtained values of the similarity factor are in the range from 50 to 100 , which indicates the similarity of the dissolution profiles of the investigated drug based on diacerein and the reference drug Arthrodarin ${ }^{\circledR}, 50 \mathrm{mg}$ capsules in buffer media with $\mathrm{pH}$ $1.2,4.5,6.8$. The developed composition of capsules based on diacerein is equivalent in dissolution kinetics to the reference drug Artrodarin ${ }^{\circledR}$.

\section{С пи сок використаної літе ратури}

1. Фіщенко В. О., Кириченко В. І., Яремин С. Ю та ін. Остеоартроз кульшового суглоба. Клінічні та соціальні аспекти захворювання. Аналітичний огляд літератури. Ч. I // Травма. - 2019. - Т. 20, № 1. C. 118-125. https://doi.org/10.22141/1608-1706.1.20.2019.158680

2. Хиць А. Р. Менеджмент больового синдрому в осіб похилого віку: фокус на нестероїдні протизапальні препарати // Укр. мед. часопис. - 2020. - Т. 1, № 6 (140). - XI/XII [Електронний ресурс]. - Режим доступу: https://www.umj.com.ua

3. Supakanya Wongrakpanich, Amaraporn Wongrakpanich, Katie Melhado, Janani Rangaswami. A Comprehensive Review of Non-Steroidal Anti-Inflammatory Drug Use in the Elderly // Aging and Disease. - 2018. - V. 9, N 1. P. 143-150. https://doi.org/10.14336/AD.2017.0306. PMCID: PMC5772852

4. Jain S., Nagori B. P., Yadav S. K. Improvement of the Dissolution Behavior of the Poorly Water Soluble Drug Diacerein by Solid Dispersion Technology and its Formulation into Tablet Dosage Form // Madridge J. Novel Drug Res. - 2018. - V. 2, Iss. 1. - P. 79-89. https://doi.org/10.18689/mjndr-1000112

5. Kaur D., Kaur J., Kamal S. S. Diacerein, its beneficial impact on chondrocytes and notable new clinical applications // Brazilian J. Pharmac. Sci. - 2019. - V. 54, N 4. - e17534. https://doi.org/10.1590/s217597902018000417534

6. De Oliveira P. G., Termini L., Durigon E. L. et al. Diacerein: A potential multi-target therapeutic drug for COVID-19 // Medical hypotheses. - 2020. - V. 144. - P. 109920. https://doi.org/10.1016/j.mehy. 2020.109920

7. Баула О. П., Салій О. О., Бессарабов В. І., Герасимчук А. М. Порівняльні дослідження кінетики розчинення лікарських засобів на основі клопідогрелю // Фармац. журн. - 2021. - Т. 76, № 1. - С. 26-34. https://doi.org/10.32352/0367-3057.1.21.03

8. Chitlange S. S., Pawbake G. R., Pandkar S. V. et al. Formulation and Evaluation of Diacerein Solid Dispersion for Solubility and Dissolution Rate Enhancement // Res. J. Pharmacy and Technol. - 2011. - V. 4, N 6. -P. 932-937.

9. Kalepu $S$., Nekkanti $V$. Insoluble drug delivery strategies: review of recent advances and business prospects // Acta Pharmac. Sinica B. - 2015. - V. 5, Iss. 5. - P. 442-453. https://doi.org/10.1016/j.apsb.2015.07.003

10. Державний реєстр лікарських засобів України [Електронний ресурс]. - Режим доступу: http:// www.drlz.com.ua/

11. Салій О. О., Куришко Г. Г., Огеренко 3. О., Гетало О. В. Порівняльні дослідження профілів вивільнення доксицикліну хіклату з твердих желатинових капсул при зміні виробників діючої речовини // Вісн. Київського нац. ун-ту технологій та дизайну. Серія Технічні науки. - 2020. - № 3 (146). C. 165-174. https://doi.org/10.30857/1813-6796.2020.3.14

12. Diacerein (2409). European Pharmacopoeia. 9th Edition. - European Directorate for the Quality of Medicines (EDQM). - Council of Europe, 67075 Strasbourg Cedex, France 2016. - 4016 p.

13. СТ-МОЗУ 42-7.2:2018 «Лікарські засоби. Дослідження біоеквівалентності». - Режим доступу: https://www.dec.gov.ua/wpcontent/uploads/attitude/1.pdf

14. Державна фармакопея України 2.0. / ДП «Український науковий фармакопейний центр якості лікарських засобів». 2-е вид. - Харків: ДП «Український науковий фармакопейний центр якості лікарських засобів», 2015. - Т. 1. - 1128 с.

\section{Re f e r e n c e s}

1. Fishchenko V. O., Kyrychenko V. I., Yaremyn S. Yu. ta in. Osteoartroz kulshovoho suhloba. Klinichni ta sotsialni aspekty zakhvoriuvannia. Analitychnyi ohliad literatury. Chastyna I // Travma. - 2019. - T. 20, № 1. - S. 118-125. https://doi.org/10.22141/1608-1706.1.20.2019.158680

2. Khyts A. R. Menedzhment bolovoho syndromu v osib pokhyloho viku: fokus na nesteroidni protyzapalni preparaty // Ukr. Med. Chasopys. - 2020. - T. 1, № 6 (140).- XI/XII. - Rezhym dostupu: https://www.umj. com.ua

3. Supakanya Wongrakpanich, Amaraporn Wongrakpanich, Katie Melhado, Janani Rangaswami. A Comprehensive Review of Non-Steroidal Anti-Inflammatory Drug Use in the Elderly // Aging and Disease. - 2018. - V. 9, N 1. P. 143-150. https://doi.org/10.14336/AD.2017.0306. PMCID: PMC5772852

4. Jain S., Nagori B. P., Yadav S. K. Improvement of the Dissolution Behavior of the Poorly Water Soluble 
Drug Diacerein by Solid Dispersion Technology and its Formulation into Tablet Dosage Form // Madridge J. Novel Drug Res. - 2018. - V. 2, Iss. 1. - P. 79-89. https://doi.org/10.18689/mjndr-1000112

5. Kaur D., Kaur J., Kamal S. S. Diacerein, its beneficial impact on chondrocytes and notable new clinical applications // Brazilian J. Pharmac. Sci. - 2019. - V. 54, N 4. - e17534. https://doi.org/10.1590/s217597902018000417534

6. De Oliveira P. G., Termini L., Durigon E. L. et al. Diacerein: A potential multi-target therapeutic drug for COVID-19 // Medical hypotheses. - 2020. - V. 144. - P. 109920. https://doi.org/10.1016/j.mehy. 2020.109920

7. Baula O. P., Saliy O. O., Bessarabov V. I., Gerasimchuk A. M. Comparative studies of the kinetics of dissolution of medicines on the basis of clopidogrel // Farmats. zhurn. - 2021. - T. 76, № 1. - S. 26-34. https:// doi.org/10.32352/0367-3057.1.21.03

8. Chitlange S. S., Pawbake G. R., Pandkar S. V. et al. Formulation and Evaluation of Diacerein Solid Dispersion for Solubility and Dissolution Rate Enhancement // Res. J. Pharmacy and Technol. - 2011. - V. 4, N 6. -P. 932-937.

9. Kalepu $S$., Nekkanti $V$. Insoluble drug delivery strategies: review of recent advances and business prospects // Acta Pharmac. Sinica B. - 2015. - V. 5, Iss. 5. - P. 442-453. https://doi.org/10.1016/j.apsb.2015.07.003

10. Derzhavnyi reiestr likarskykh zasobiv Ukrainy. - Rezhym dostupu: http://www.drlz.com.ua/

11. Saliy O. O., Kuryshko H. H., Oherenko Z. O., Getalo O. V. Comparative studies of the release profiles of doxycycline hyclate from solid gelatin capsules when replacing the producers of the active substance // Visn. Kyivskoho nats. un-tu tekhnolohii ta dyzainu. Seriia Tekhnichni nauky. - 2020. - № 3 (146). - S. 165-174. https://doi.org/10.30857/1813-6796.2020.3.14

12. Diacerein (2409). European Pharmacopoeia. 9th Edition. - European Directorate for the Quality of Medicines (EDQM). - Council of Europe, 67075 Strasbourg Cedex, France 2016. - 4016 p.

13. Nastanova ST-MOZU 42-7.2:2018 «Likarski zasoby. Doslidzhennia bioekvivalentnosti». - Rezhym dostupu: https://www.dec.gov.ua/wp-content/ uploads/attitude/1.pdf

14. Derzhavna farmakopeia Ukrainy 2.0 / DP «Ukrainskyi naukovyi farmakopeinyi tsentr yakosti likarskykh zasobiv». 2-e vyd. - Kharkiv: DP «Ukrainskyi naukovyi farmakopeinyi tsentr yakosti likarskykh zasobiv», 2015. - T. 1. $-1128 \mathrm{~s}$

Надійшла до редакції 24 листопада 2021 р. Прийнято до друку 29 листопада 2021 р.

О. О. Салій ${ }^{1}$ (https://orcid.org/0000-0001-7103-2083),

O. В. Лось ${ }^{2}$ (https://orcid.org/0000-0002-7830-6937),

О. П. Баула ${ }^{1}$ (https://orcid.org/0000-0003-4305-6517),

В. Ю. Турчина ${ }^{1}$ (https://orcid.org/0000-0003-3046-5549)

${ }^{1}$ Київський національний університет технологій та дизайну

${ }^{2}$ Фармачевтична корпорачія «Юрія-Фарм», м. Київ

РОЗРОБЛЕННЯ СКЛАДУ І ОЦІНКА ЕКВІВАЛЕНТНОСТІ ТВЕРДИХ ЖЕЛАТИНОВИХ КАПСУЛ

ДІАЦЕРЕЇНУ

Ключові слова: діацереїн, розчинність, фармакотехнологічні властивості, кінетика розчинення

А Н О Т А Ц І Я

Діацереїн - нового покоління симптоматичний засіб повільної дії для лікування остеоартрозу, при пероральному прийомі виявляє помірну протизапальну та знеболювальну активність, уповільнює розпад хрящової тканини і полегшає біль і набряк, але за фізико-хімічними властивостями практично нерозчинний у воді і належить до II класу БСК, завдяки чому лише 35-56\% препарату досягає системної циркуляції. Отже, пошук підходів підвищення швидкості розчинення практично нерозчинного АФІ за допомогою рецептури, виду допоміжних речовин, ступеня розчинності та кінетики вивільнення субстанції $з$ твердих желатинових капсул мають забезпечити гарантовану ефективність препарату

Мета роботи - розроблення складу препарату у формі твердих желатинових капсул на основі діацереїну, експериментальне дослідження розчинності діацереїну та оцінка складу дослідженням кінетики розчинення лікарського засобу.

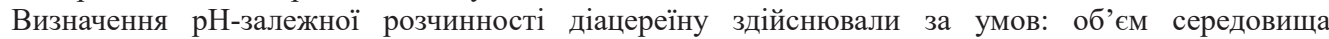
розчинення 250 мл, температура розчинення $37,0 \pm 1,0{ }^{\circ} \mathrm{C}$. Досліджували найвищу рекомендовану до застосування одноразову дозу 50 мг. Розроблення складу лікарського засобу Діацереїн, капсули, 50 мг здійснювали зі застосуванням різних видів допоміжних речовин та їх модифікацій для досягнення належних технологічних властивостей щодо текучості (сипучості) та короткого часу розпаду капсул для вивільнення діючої речовини. Порівняльні дослідження кінетики розчинення здійснювали методом in vitro за тестом «Розчинення» 3 використанням приладу з лопаттю зі швидкістю обертання 75 об/хв, середовища розчинення зі значення $\mathrm{pH}$ 1,2, 4,5 та 6,8, у об'ємі 900 мл за температури $37 \pm 0,5{ }^{\circ} \mathrm{C}$. Як референтний лікарський засіб використано «Артродарин®», капсули, 50 мг, виробництва TRB PHARMA S. А., Аргентина. 
Встановлено, що діацереїн практично нерозчинний у буферному розчині з $\mathrm{pH}$ 1,2, має відносно низьку розчинність у буферному розчині з $\mathrm{pH} 4,5$, при цьому розчинність діацереїну підвищується 3 ростом $\mathrm{pH}$ середовища до 6,8. Розроблено оптимальний склад капсул з діацереїном за технологією вологої грануляції. Одержані дані насипної густини та коефіцієнту Карра вказують на задовільну плинність маси для капсулювання. Здійснено порівняльні дослідження кінетики розчинення досліджуваного лікарського засобу та оригінального препарату «Артродарин®», капсули по 50 мг. За проведеними розрахунками всі одержані значення фактора подібності становлять в межах від 50 до 100 , та свідчать про подібність у буферних середовищах із $\mathrm{pH}$ 1,2; 4,5 та 6,8. Розроблений склад препарату $\epsilon$ еквівалентним за кінетикою розчинення до оригінального препарату.

О. О. Салий ${ }^{1}$ (https://orcid.org/0000-0001-7103-2083),

О. В. Лось ${ }^{2}$ (https://orcid.org/0000-0002-7830-6937),

О. П. Баула ${ }^{1}$ (https://orcid.org/0000-0003-4305-6517),

В. Ю. Турчина ${ }^{1}$ (https://orcid.org/0000-0003-3046-5549)

${ }^{1}$ Киевский национальный университет технологий и дизайна

${ }^{2}$ Фармачевтическая корпорачия «Юрия-Фарм», г. Киев

РАЗРАБОТКА СОСТАВА И ОЦЕНКА ЭКВИВАЛЕНТНОСТИ ТВЕРДЫХ ЖЕЛАТИНОВЫХ КАПСУЛ ДИАЦЕРЕИНА

Ключевые слова: диацереин, растворимость, фармако-технологические свойства, кинетика растворения А Н Н О Т А ЦИ Я

Диацереин - нового поколения симптоматическое средство замедленного действия для лечения остеоартроза, при пероральном приеме проявляет умеренную противовоспалительную и обезболивающую активность, замедляет распад хрящевой ткани и облегчает боль и отек, но по физикохимическим свойствам практически нерастворим в воде, благодаря чему только 35-56\% препарата достигает системной циркуляции. Исходя из этого, поиск подходов увеличения скорости растворения практически нерастворимого АФИ с помощью рецептуры, вида вспомогательных веществ, степени растворимости и кинетики высвобождения субстанции из твердых желатиновых капсул должен обеспечить гарантированную эффективность препарата.

Цель работы - разработка состава препарата в форме твердых желатиновых капсул на основе диацереина, экспериментальное исследование растворимости диацереина и оценка состава исследованием кинетики растворения лекарственного средства.

Определение $\mathrm{pH}-$ зависимой растворимости диацереина осуществляли в условиях: объем среды растворения 250 мл, температура растворения $37,0 \pm 0,5{ }^{\circ} \mathrm{C}$. Исследовали высшую рекомендованную к применению однократную дозу 50 мг. Разработку состава лекарственного средства Диацереин, капсулы, 50 мг проводили с применением разных видов вспомогательных веществ и их модификаций для достижения надлежащих технологических свойств по текучести (сыпучести) и быстрого периода распада капсул для высвобождения действующего вещества. Сравнительные исследования кинетики растворения осуществляли методом in vitro, тест «Растворение» с использованием прибора с лопастью со скоростью вращения 75 об/мин, среды растворения со значением рН 1,2, 4,5 и 6,8, в объеме 900 мл при температуре $37 \pm 0,5^{\circ} \mathrm{C}$. В качестве референтного лекарственного средства использовали «Артродарин ${ }^{\circledR}$ », капсулы, 50 мг, производства TRB PHARMA S.A., Аргентина.

Установлено, что диацереин практически нерастворим в буферном растворе с $\mathrm{pH} 1,2$, имеет относительно низкую растворимость в буферном растворе с $\mathrm{pH} 4,5$, при этом растворимость диацереина повышается с увеличением $\mathrm{pH}$ среды до 6,8. Разработан оптимальный состав капсул с диацереином по технологии влажной грануляции. Полученные данные насыпной плотности и коэффициента Карра указывают на удовлетворительную текучесть капсулированной массы. Проведены сравнительные исследования кинетики растворения исследуемого лекарственного средства и оригинального препарата «Артродарин®», капсулы по 50 мг. По проведенным расчетам все полученные данные фактора подобия находяться в пределах от 50 до 100, что свидетельствует о подобии в буферных средах с рН 1,2, 4,5 и 6,8 . Разработанный состав препарата является эквивалентным по кинетике растворения оригинальному препарату. 
O. O. Saliy ${ }^{1}$ (https://orcid.org/0000-0001-7103-2083),

O. V. Los ${ }^{2}$ (https://orcid.org/0000-0002-7830-6937),

O. P. Baula ${ }^{1}$ (https://orcid.org/0000-0003-4305-6517),

V. Yu. Turchina ${ }^{1}$ (https://orcid.org/0000-0003-3046-5549)

${ }^{1}$ Kiev National University of Technology and Design

${ }^{2}$ Pharmaceutical corporation «Yuria-Pharm», Kiev

DEVELOPMENT OF THE COMPOSITION AND EQUIVALENCE EVALUATION OF SOLID GELATIN CAPSULES DIACEREIN

Key words: diacerein; solubility; pharmaco-technological properties; dissolution kinetics

A B S T R A C T

Diacerein is a new generation of symptomatic slow-acting agent for the treatment of osteoarthritis, when taken orally, it exhibits moderate anti-inflammatory and analgesic activity, slows down the decay of cartilage tissue and relieves pain and swelling, but its physicochemical properties it is practically insoluble in water, due to which only $35-56 \%$ the drug reaches systemic circulation. Therefore, the search for approaches to increase the dissolution rate of a practically insoluble API using the formulation, type of excipients, degree of solubility and kinetics of the substance release from hard gelatin capsules should provide guaranteed drug efficacy.

The aim of the work is to develop the composition of the drug in the form of hard gelatin capsules based on diacerein, to experimentally study the solubility of diacerein, and to evaluate the composition by studying the kinetics of dissolution of the drug.

Determination of the $\mathrm{pH}$-dependent solubility of diacerein was carried out in the conditions: the volume of the dissolution medium is $250 \mathrm{ml}$; dissolution temperature $37.0 \pm 0.5^{\circ} \mathrm{C}$. The highest recommended single dose of $50 \mathrm{mg}$ was investigated. The development of the composition of the drug Diacerein, capsules, $50 \mathrm{mg}$ was carried out with the use of various types of excipients and their modifications to achieve the proper technological properties in terms of fluidity (flowability) and a short disintegration time of the capsules for the release of the active substance. Comparative studies of the kinetics of dissolution were carried out by the in vitro method, the test «Dissolution» was studied a «Paddle apparatus» with a rotation speed of $75 \mathrm{rpm}$, a dissolution medium with a $\mathrm{pH}$ value of $1.2,4.5$ and 6.8 , in a volume of $900 \mathrm{ml}$ at a temperature of $37 \pm$ $0.5^{\circ} \mathrm{C}$. The reference drug was used «Artrodarin ${ }^{\circledR} »$, capsules of $50 \mathrm{mg}$, manufactured by TRB PHARMA S. A.,vArgentina.

It was found that diacerein is practically insoluble in a buffer solution with a $\mathrm{pH}$ of 1.2 , has a relatively low solubility in a buffer solution with a $\mathrm{pH}$ of 4.5 , while the solubility of diacerein increases with an increase in the $\mathrm{pH}$ of the medium to 6.8 . The optimal composition of capsules with diacerein using the wet granulation technology has been developed. The obtained data for bulk density and Carr\&apos;s index indicate satisfactory flowability of the encapsulating mass. Comparative studies of the dissolution kinetics of the investigational medicinal product and the original drug «Artrodarin $(\AA$ ), capsules of $50 \mathrm{mg}$ were carried out. According to the calculations, all the obtained values of the similarity factor are in the range from 50 to 100 and indicate the similarity in buffer media with $\mathrm{pH} 1.2,4.5$ and 6.8. The developed composition of the preparation is equivalent in dissolution kinetics to the original medicine.

\title{
Електронна адреса для листування з авторами: saliy.oo@knutd.edu.ua
}

\author{
(Салій О. О.)
}

